\title{
Incomuns entre nós: um relato em múltiplas vozes sobre processos audiovisuais colaborativos com Coletivos e a produção compartilhada de conhecimento*
}

\author{
Uncommon among us: a multi-voice account of collaborative \\ audiovisual processes with Collectives and the \\ shared production of knowledge
}

Incomunes entre nosotros: un relato a varias voces de procesos audiovisuales colaborativos con Colectivos y la producción compartida de conocimiento

\section{Isabela Umbuzeiro Valent}

Graduada em Terapia Ocupacional, Mestra em Estética e História da Arte e Doutora em Artes pela Universidade de São Paulo, Brasil, com estágio sanduíche na Universidade Aberta de Lisboa, Portugal. Professora substituta na Universidade Federal de Pernambuco. Foi bolsista FAPESP e CAPES. E-mail: isabelauv@gmail.com

\section{Jayme Valarelli Menezes}

Graduado em Comunicação Social pela Universidade Presbiteriana Mackenzie, Brasil, mestrando no Programa de Pós-Graduação Humanidades, Direitos e Outras Legitimidades na Universidade de São Paulo, Brasil, e bolsista CAPES. E-mail: jayme.menezes@usp.br

\footnotetext{
* Agradecemos à Fundação de Amparo à Pesquisa do Estado de São Paulo - FAPESP (processo no 2016/17723-3). Agradecemos também à Coordenadoria de Aperfeiçoamento do Ensino Superior (CAPES) pela bolsa sanduíche concedida para realização de estágio no Centro de Estudos de Migrações e Relações Interculturais da Universidade Aberta de Lisboa (Portugal) e pelo financiamento do programa onde a pesquisa foi realizada. Ao Laboratório de Estudos e Pesquisa Arte Corpo e Terapia Ocupacional (Pacto) da Universidade de São Paulo, pela parceria e agenciamento dessa rede. Ao Centro de Convivência É de Lei pelo apoio para realização das oficinas. À Zine Filmes que colaborou na realização das filmagens e na montagem audiovisual do acervo. À Rico Filmes que colaborou na pós-produção do filme Incomuns. À 83 Multimídia que colaborou na elaboração do site Incomuns. E, aos participantes da oficina audiovisual e dos Coletivos acompanhados pela generosidade na cocriação deste projeto.
} 


\section{Resumo}

A partir do olhar e da voz de dois participantes de um processo colaborativo de pesquisa, apresentamos a experiência de uma oficina audiovisual que documentou coletivos que produzem arte, cultura e cuidado em espaços públicos da cidade de São Paulo, que também acolhem pessoas em situações de vulnerabilidade. Juntos, realizamos o documentário "Incomuns" e um acervo digital com as produções audiovisuais. Para que vozes dissonantes pudessem compor o processo de criação, praticamos formas de trabalho experimentais que produziram convivência e a circulação pela cidade. O dispositivo instaurou um processo coletivo, articulando redes e trocas, fortalecendo a organização dos projetos bem como encontros inusitados. Neste relato, apresentamos como o processo foi vivido pela perspectiva dos participantes e reflexões sobre as potências e os desafios da produção compartilhada de conhecimento e desta criação coletiva.

Palavras-chave: coletivos artísticos; processos colaborativos audiovisuais; produção compartilhada do conhecimento; saúde mental.

\section{Introdução ${ }^{1}$}

La documentación no sólo hace visible el aprendizaje, sino que lo hace compartido: lo socializa, lo formaliza y lo abre. (Lafuente; Gómez; Freire, 2018:47)

Escrevemos este relato com duas das muitas vozes e olhares presentes em uma experiência audiovisual, que aconteceu no âmbito de uma pesquisa de doutorado. Trata-se de uma proposta colaborativa desenvolvida em parceria com coletivos artísticos e culturais da cidade de São Paulo que têm em comum formas não convencionais de criação e a tessitura de redes de cuidado e saúde mental como um dos efeitos de suas ações. São coletivos que acolhem a participação de qualquer pessoa, independente de sua condição social ou de saúde, inclusive aquelas consideradas vulneráveis por questões ligadas à saúde mental, deficiências ou vulnerabilidade social. Alguns deles estão envolvidos desde a década de 1990 com o movimento da luta antimanicomial, que reivindica o direito ao cuidado de pessoas com sofrimento psíquico em liberdade e busca criar espaços de acolhimento da loucura nos espaços de convívio social.

Em uma oficina audiovisual com duração de 2 meses, reunimos 30 pessoas, membros de 7 Coletivos diferentes ${ }^{2}$, os quais, com suas singularidades, realizam ações artísticas, mas também

\footnotetext{
${ }^{1}$ Este relato é uma versão ampliada e revisada de um trabalho apresentado no I Colóquio de Antropologia e Cinema da Amazônia, realizado entre os dias 05 e 10 de novembro de 2019, Belém/PA. O trabalho deriva de uma pesquisa de doutorado realizada no Programa Interunidades em Estética e História da Arte da Universidade de São Paulo (PGEHA) por Isabela Umbuzeiro Valent com orientação da Dra. Eliane Dias de Castro.

${ }^{2}$ Coletivos participantes: Cia Teatral Ueinzz; Coral Cênico Cidadãos Cantantes, Oficina de Dança e Expressão Corporal - ODEC; Coletivo Preguiça; Ponto de Cultura É de Lei; Ponto Benedito e; Clínica Pública de Psicanálise. $\mathrm{Na}$ tese elaborada (Valent, 2019) e no site do projeto encontram-se informações sobre cada um deles. Ao longo do texto nos referirmos à Coletivos, com inicial maiúscula, quando se trata das propostas acompanhadas pela pesquisa e; à coletivos, com inicial minúscula, quando se trata de qualquer prática coletiva.
} 
práticas de cuidado promovendo ambientes que produzem saúde. Cada iniciativa nasce em momentos diferentes e com intuitos distintos.

Das sete, o Coral Cênico Cidadãos Cantantes, que existe desde 1992, é a mais antiga e que dura há mais tempo. Nasceu da inquietação de uma psicóloga, trabalhadora da rede de saúde mental do município de São Paulo, que buscou espaços culturais para abrigar um coro cênico musical reunindo pessoas egressas de hospitais psiquiátricos ou que frequentavam serviços de saúde mental, além de serem abertos à participação de toda comunidade.

A Oficina da Dança e Expressão Corporal (ODEC), nasce em 2001 como um desdobramento do Cidadãos Cantantes. Inicialmente proposta para oferecer o preparo e a experimentação do movimento corporal para os coralistas, ela ganha força e autonomia ao longo dos anos, culminando em um espaço para a prática da dança e do movimento a partir da improvisação, dos afetos e das relações. Em encontros semanais e em apresentações pelos espaços públicos da cidade, a ODEC também é aberta à participação de qualquer pessoa e vem praticando formas experimentais de organização coletiva e criação de interações pelo movimento no encontro entre os diferentes corpos presentes.

Já a Clínica Pública de Psicanálise é a iniciativa mais recente. Surge em 2016 como uma experiência piloto do exercício da psicanálise pública em um centro cultural criado em um território em disputa na cidade: a Vila Itororó. Em 2020, o Coletivo de psicanalistas encerrou a experiência.

Os outros 5 Coletivos acompanhados têm, pelo menos, 10 anos de existência continuada. Apenas dois deles se inscrevem formalmente em organizações da sociedade civil: o Ponto de Cultura É de Lei, ligado ao Centro de Convivência É de Lei, uma organização que realiza ações de redução de riscos e danos sociais e à saúde associados ao uso de drogas desde 1997, promovendo atividades artísticas e culturais no centro da cidade para um público diverso, incluindo pessoas em situações de intensa vulnerabilidade social e; o Ponto Benedito de Cultura e Economia Solidária, que é ligado à Associação Vida em Ação e funciona como um espaço cultural para circulação de criações artísticas e a comercialização de produções artesanais ligadas à rede de saúde mental e economia solidária.

Há também a Cia. Teatral Ueinzz, que nasceu em 1997 em um instituto de saúde mental, mas que hoje ensaia em um centro cultural privado e realiza performances em diversas mostras e espaços artísticos no Brasil e no exterior. Sua pesquisa criativa navega pelas beiras do inominável e o grupo é composto por pessoas com trajetórias pela saúde mental, sejam profissionais ou usuários de serviços, filósofos e artistas que trabalham com diversas linguagens para além do teatro. 
E, por fim, o Coletivo Preguiça, que reúne artistas, terapeutas ocupacionais, participantes de serviços de saúde mental e a comunidade em geral desde 2008. Atualmente, ocupa semanalmente uma área de convivência de um centro cultural público para produzir criações diversas a partir de práticas artísticas.

Algumas das iniciativas se autodenominam Coletivos, outras não necessariamente se identificam a partir dessa nomenclatura. Mas elas têm em comum características em suas formas de organização, que são próprias do que a literatura recente tem apontado como uma categoria analítica diferencial em relação a outras experiências organizacionais, políticas e de socialização (Marques; Marx, 2020). São marcadas por uma dinâmica que habita a vida cotidiana das pessoas que delas participam, por uma flexibilidade que responde mais às necessidades circunstanciais dos sujeitos e suas interações no território do que a uma lógica formal ou estruturada. No entanto, é possível notar que essas iniciativas perduram ao longo do tempo de forma mais continuada do que ações ligadas a propostas institucionais ou programas de políticas públicas nas áreas da saúde e da cultura. Refletir sobre o que sustenta a existência continuada delas foi um dos focos da pesquisa.

Apesar do longo tempo de existência, são práticas que foram pouco documentadas e sistematizadas. Elas nos contam sobre o acolhimento a tudo aquilo que desvia dos padrões normativos, integrando pessoas que, muitas vezes, acabam encarceradas, institucionalizadas ou com sua circulação restrita aos programas assistenciais de saúde. O tipo de organização, sustentação das ações e manejos das relações operadas por estes Coletivos fornecem reflexões importantes sobre a vida em comum nas cidades e a convivência entre diferentes como elementos de produção da saúde mental. Dessa forma, a documentação, sistematização e reflexão sobre essas experiências vivas contribuem para a discussão sobre como a coletividade cria outras políticas do cuidado.

Entre outubro e dezembro de 2018, realizamos filmagens e entrevistas documentando o processo de cada iniciativa. A experiência gerou o documentário Incomuns, um média metragem, que reúne a memória de todos os Coletivos; 7 curtas-metragens sobre cada um deles e 32 entrevistas na íntegra. Os filmes estão disponíveis em um site que reúne o acervo audiovisual produzido $^{3}$. Além da contribuição dessa documentação para o campo das ciências sociais e da saúde, a metodologia colaborativa proporcionou a construção de um conhecimento compartilhado entre aqueles que sustentam e participam dos Coletivos, agentes de políticas públicas e estudantes.

\footnotetext{
${ }^{3} \mathrm{O}$ acervo pode ser acessado no seguinte endereço: https://www.incomuns.art.br/
} 
Este relato tem como foco a relação proporcionada pelo dispositivo colaborativo da pesquisa, expondo como ele foi vivido pelas pessoas envolvidas. Apresentamos, a seguir, uma narrativa múltipla escrita em primeira pessoa a partir da perspectiva de cada autor em um único texto, com o objetivo de tornar visível nuances de como se deu o processo compartilhado de produção audiovisual na visão de diferentes participantes. Cada voz é marcada por uma cor diferente: em azul escuro, a voz de Isabela, que coordenou a oficina e é a realizadora da pesquisa de doutorado, em laranja, a voz de Jayme, que foi um dos colaboradores da oficina e é performer da Companhia Teatral Ueinzz, um dos Coletivos participantes ${ }^{4}$.

Com essa proposta, desejamos mostrar as singularidades do ato vivo de fazer pesquisa, na dimensão da produção compartilhada de conhecimento. $\mathrm{O}$ relato em primeira pessoa, partindo da voz de cada envolvido no processo, pretende dar a ver nuances de como a documentação, a reflexão e a produção de memórias dependem da participação de múltiplas pessoas envolvidas, que vivem o processo a partir de suas necessidades, desejos e pontos de vista. Com este passeio pelas duas vozes, pretendemos também evidenciar e, ao mesmo tempo, embaralhar as diferentes implicações e relações de poder geradas pelo dispositivo acadêmico, seus aspectos afetivos e as redes implícitas de cuidado e apoio que mobilizam esse fazer em conjunto. Por meio da narrativa em relato, pretendemos mostrar a materialidade de um método aberto à interlocução dos colaboradores e às singularidades desse modo de fazer pesquisa.

\section{Relato em duas vozes}

Em 2017, quando estava desenvolvendo uma pesquisa de doutorado, tive a ideia de juntar Coletivos que produzem arte, cultura e cuidado para que pudéssemos nos (re)conhecer e documentar o que fazem e como se sustentam. Eu havia entrado em contato alguns deles quando cursei Terapia Ocupacional na USP, no início dos anos 2000. Depois de formada, segui a acompanhar essas ações e trabalhei na construção do Ponto de Cultura É de Lei, uma iniciativa da sociedade civil que realiza ações culturais e artísticas como uma das estratégias de redução de riscos e danos sociais e à saúde associados ao uso de drogas. Na prática, um centro de convivência: uma pequena sala de um prédio comercial, no centro da cidade de São Paulo. Lá, todos eram bem-vindos e se podia chegar a qualquer momento. Lá, aprendi a habitar espaços comuns, dialogar com pessoas completamente diversas entre si. Mas, sobretudo, aprendi a escutar os saberes que vêm das ruas, de quem opta por não mais corresponder ao sistema normativo da vida em sociedade. Lá, aprendi também que sustentar aquilo tudo era um sufoco. Eu era a pessoa que coordenava as ações culturais e fazia uma espécie de tradução entre essa

\footnotetext{
${ }^{4} \mathrm{O}$ texto na cor preta se refere a nossa voz coletiva e a de outros autores citados.
} 
linguagem errante e aberta e a formatação de projetos sociais e culturais para que pudéssemos ter recursos financeiros e condições para realizar os projetos.

Eu também frequentava outros Coletivos vizinhos, como o Coral Cênico Cidadãos Cantantes e a Oficina de Dança e Expressão Corporal (ODEC), que aconteciam ali do lado do É de Lei, em um espaço cultural público chamado Galeria Olido, numa sala toda de vidro que dá para a rua. Essas iniciativas acolhem pessoas em diversas condições, incluindo algumas em situação de rua. Reúnem pessoas com deficiência, crianças, ricos, pobres, com trajetórias pelos serviços de saúde mental, que acabaram de sair da prisão... Todo mundo ali, junto e misturado.

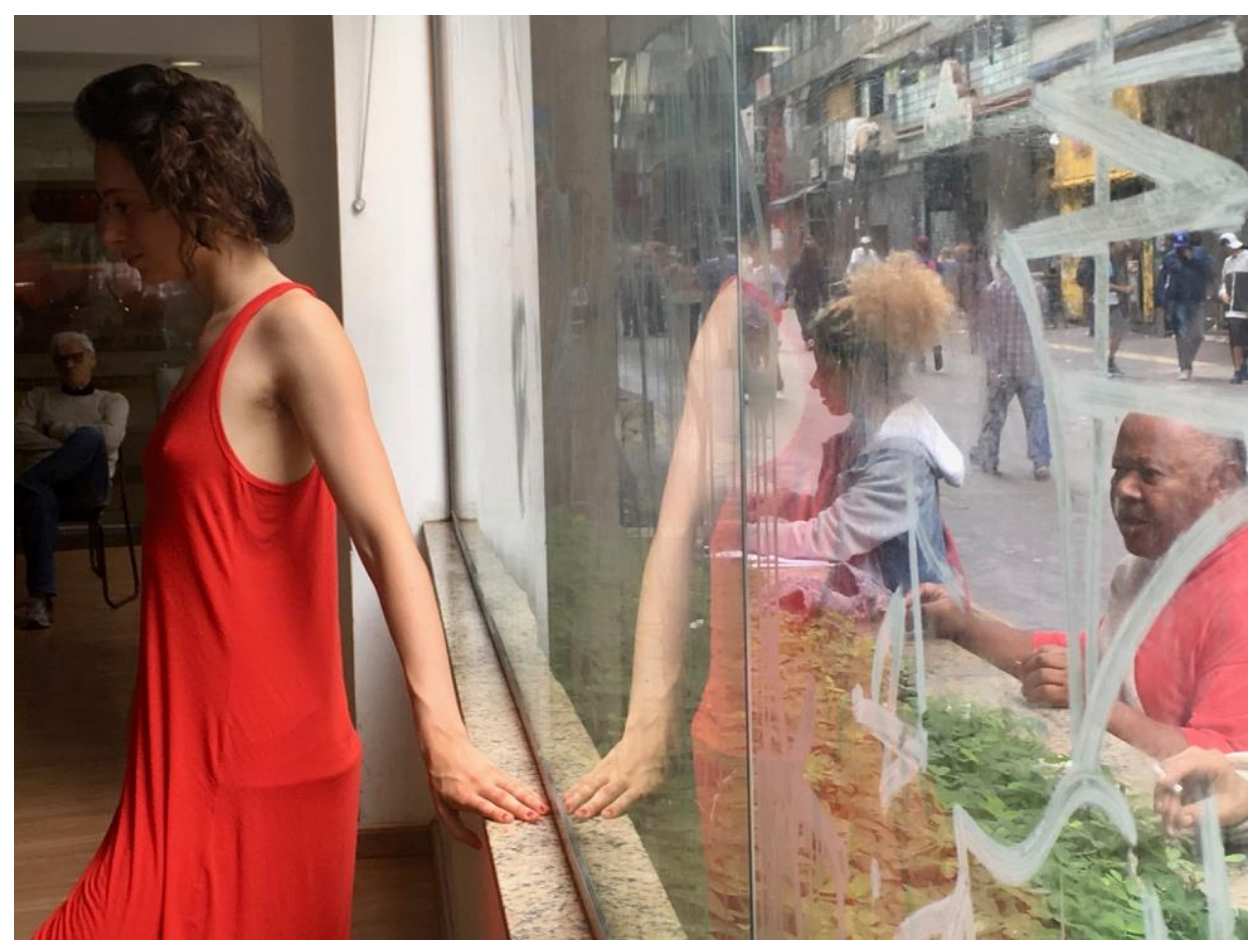

Encontro da Oficina de Dança e Expressão Corporal.

Foto: Isabela Valent

Quando trabalhava no Centro de Convivência É de Lei, entre 2011 e 2017, me lembro de sair das reuniões para almoçar nas redondezas, na sexta-feira de manhã, e de ver os dançantes pelas janelas de vidro da Galeria. Desde 2004, o grupo se reúne todas as sextas-feiras de manhã para dançar. Às vezes, eles até saiam da sala e a gente dançava com eles na rua. Mas eu estava sempre muito ocupada, porque tinha que prestar contas, fazer projetos, reuniões etc. Quase nunca podia dançar. No entanto, como parte das atividades que eu realizava no É de Lei, propunha ocupações culturais no Largo Paissandu, ali do lado, com cinema na praça e sarau aberto. O Coral Cênico Cidadãos Cantantes vinha cantar, os dançantes então se deliciavam, e o Luís, da ODEC, sempre dava um jeito de me fazer alçar voo, me arrastando em dança pela praça. 
Mostrávamos os filmes feitos nas oficinas de cinema e fotografia do É de Lei no nosso improvisado cine-carroça.

$\mathrm{Eu}$ olhava todos aqueles movimentos coletivos e ficava pensando sobre quanta experimentação havia para que eles existissem. Quantas pessoas, cada uma com sua presença, contribuíam para que aqueles espaços de respiro, de convivência entre diferentes, de alegria e de criação fossem possíveis. Circulava pelos Coletivos e indagava sobre como fazer para que a sabedoria dessas experiências pudesse ser vista e escutada por mais pessoas, mesmo entre os próprios participantes, que muitas vezes nem se conheciam. Resolvi levar essas questões para uma pesquisa de doutorado, no intuito de documentar e compartilhar tudo aquilo que eu conseguia ver por meio dessa convivência. Além disso, eu também tinha o desejo de refletir conjuntamente sobre os desafios que enfrentávamos para a sustentação e gestão desses projetos.

$\mathrm{Na}$ época, eu estava frequentando uma disciplina de antropologia audiovisual e muito curiosa para pensar como propor um processo de produção compartilhada, como fazia Jean Rouch. A câmera participante, nas experiências do cineasta-pesquisador, cria possibilidades de comunicação entre quem pesquisa e as pessoas que ele "observa". Diante desse fenômeno, ele afirma que

(...) essa informação, a posteriori em um filme está apenas a começar, mas ela já introduz relações completamente novas entre antropólogo e o grupo que ele estuda, primeira fase do que alguns de nós já chamam "antropologia partilhada". O observador sai por fim da sua torre de marfim; a sua câmera, o seu gravador e o seu projetor conduziram-no por um estranho caminho de iniciação no próprio coração do conhecimento e, pela primeira vez, é julgado pelos próprios feitos, não por um júri de tese, mas pelos próprios homens que veio observar (Rouch, [1973] 2011:77-78).

Então, propus um espaço de produção e criação compartilhada com eles. Para começar, fiz um primeiro contato, mediado pelo Laboratório de Estudos e Pesquisa Arte, Corpo e Terapia Ocupacional (Pacto) da Faculdade de Medicina da Universidade de São Paulo (USP), onde eu me formei na graduação, e que tinha parceria com várias dessas iniciativas. Essa parceria se dava pela inserção de estudantes de Terapia Ocupacional em estágios realizados nos Coletivos com foco no tema da produção da saúde e as práticas artísticas e culturais. Eu mesma fui uma das primeiras estagiárias do Coral Cênico Cidadãos Cantantes, em 2007.

Então, fiz uma visita em cada um dos parceiros do Pacto em 2018 e os convidei para participar da pesquisa por meio de registros audiovisuais do cotidiano dos grupos. Eles toparam. Para que a câmera começasse a circular, sem que fosse operada por alguém de fora do acontecimento, propus para as estagiárias que elas circulassem durante algumas semanas com uma câmera filmadora pelos projetos dos quais participavam, registrando o que chamasse a atenção delas. Às vezes, a câmera circulava passando de mão em mão entre outros participantes. 
Depois, elas entregavam a câmera de uma para outra e, entre esses movimentos, me enviavam os arquivos com os vídeos das filmagens. Eu os recebia e descobria imagens que me impressionavam.

Chamava atenção a forte presença de corpos em situações de encontro em diferentes configurações: pessoas ocupam mesas do espaço de convivência de um centro cultural público onde produzem pinturas, esculturas, vídeos, fotografias, conversas e um lanche coletivo. Alguns ouvem música e dançam. Outros passam, conversam um pouco e logo se vão. Noutra experiência, usuários de um serviço de saúde mental se encontram em um centro cultural onde planejam saídas pela cidade em uma ação mediada pelas estagiárias. Silêncios, estranhamentos e conflitos fazem parte das negociações. Uma das participantes não se comunica através da fala e assim convoca a todos para experimentar diferentes formas de comunicação. Quando circulam pela cidade, eles parecem precisar ajustar constantemente ritmos e conexões para seguirem juntos sem a necessidade de uniformizar a caminhada. Em outras imagens, via corpos que ensaiavam experimentos cênicos numa galeria da arte. Às vezes, combinam o que será feito, outras vezes, parecem viver uma constante improvisação. Alguns dormem, outros assistem. Alguns falam, outros não. $\mathrm{O}$ espaço parece aberto às formas pouco convencionais do que se entende por um ensaio teatral.

Com essas imagens, editei um vídeo para cada experiência com praticamente todo o material filmado. Fiz então uma nova visita aos Coletivos afim de apresentar a montagem, para que eles pudessem se ver em ação. As reações, em cada um, foram muito diferentes, e era um momento de troca e diálogo. Alguns não falavam, mas se reconheciam no vídeo, outros ficavam desinteressados, outros animados com a ideia de produzir mais vídeos sobre o que faziam. Nessas visitas, apresentei a proposta de continuidade da pesquisa, convidando os participantes para uma Oficina Audiovisual para Coletivos Artísticos, de modo que a câmera pudesse circular pelas mãos dos participantes dos Coletivos e eles mesmos pudessem produzir as filmagens. Eu sabia também que cada Coletivo praticava estratégias para lidar com problemas que eram similares, mas eles não se conheciam. Então meu plano era de que essa zona de contato pudesse gerar trocas e produções de conhecimento entre eles. Apostava que o encontro seria rico para gerar uma contaminação entre todos, onde eles pudessem ser vistos e se ver uns nos outros.

Então começamos com uma oficina aberta, para a qual convidei um realizador audiovisual, que, por sua vez, convidou um produtor e fotógrafo. Usei recursos financeiros da reserva técnica do projeto de pesquisa para contratar seus serviços. Convidei também uma estudante de terapia ocupacional, a Yasmin, para apoiar todo o processo e auxiliar a organizar e manejar o trabalho em grupo. Fizemos uma parceria com o Ponto de Cultura É de Lei, que tinha 
equipamentos audiovisuais e uma sala disponível para o trabalho. A oficina foi aberta a qualquer pessoa com interesse na proposta e divulgamos para a rede que frequenta as iniciativas.

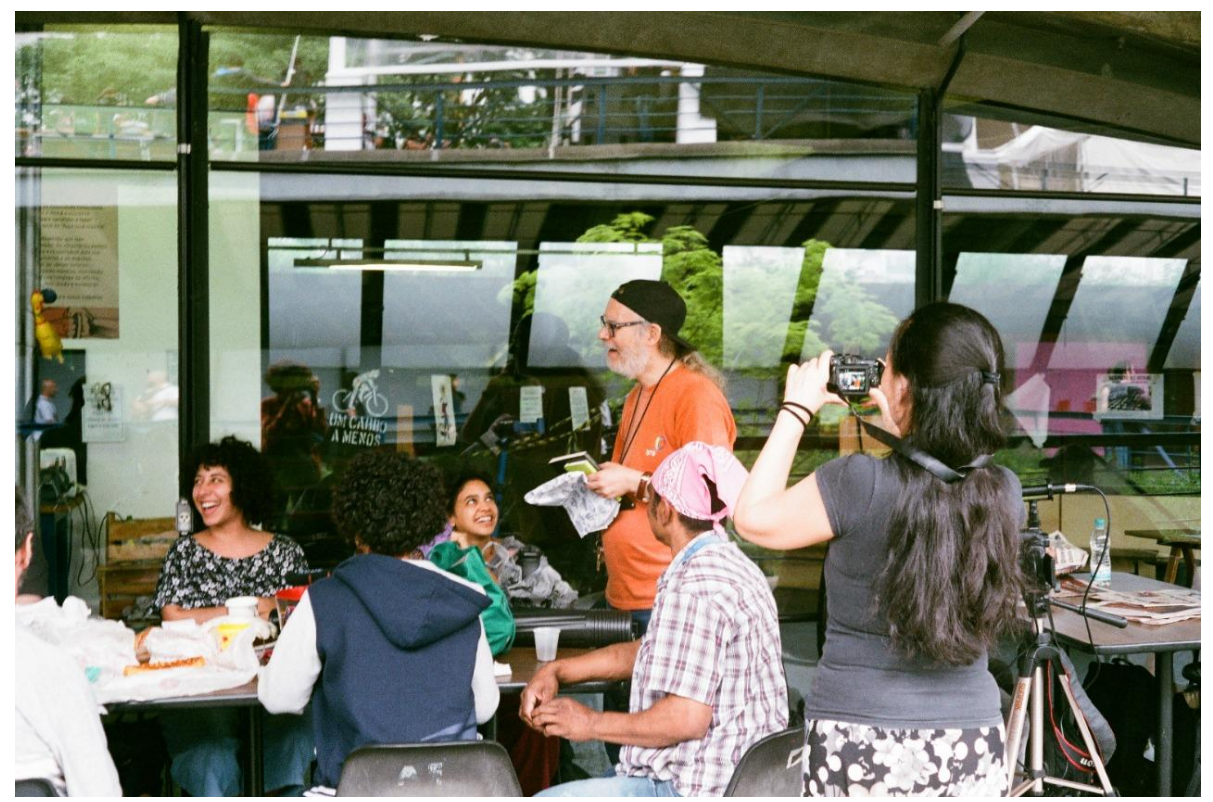

Oficina audiovisual filma o Coletivo Preguiça.

Foto: Yasmin Lopes

Lembro da tarde em que a Isabela convidou o grupo para a oficina audiovisual. O grupo

se chama Ueinzz; é um grupo de teatro. Só para contextualizar, o grupo nasceu em um hospitaldia psiquiátrico ${ }^{5}$ e existe há mais de 20 anos. É formado por pacientes psiquiátricos, que não são necessariamente atores profissionais, e por artistas, filósofos, professores, psiquiatras e terapeutas ocupacionais. O grupo se encontra toda quarta-feira à tarde para ensaiar, das as $14 \mathrm{~h}$ às 16h, em um teatro dentro de uma galeria de arte chamada B_arco, em Pinheiros, na cidade de São Paulo. Lembro que a Erika, também terapeuta ocupacional e integrante do Ueinzz, anunciou que uma pessoa iria fazer um convite para o grupo. A Isabela então convidou a gente para participar de uma oficina de audiovisual que era parte do processo de seu trabalho de doutorado.

Minha primeira reação, confesso, foi do mais puro desinteresse. O que lá quero eu saber sobre audiovisual? Lembro, por outro lado, que alguns atores do grupo queriam participar. O Rodrigo, por exemplo, estava empolgado. Um outro integrante do grupo também se interessou. A Erika argumentava tentando nos incentivar a participar. Iriam participar da oficina outros Coletivos artísticos em um espaço público chamado É de Lei.

A Erika disse: Vai sim Jayme, você vai representar o grupo. Fiquei revoltado. Quem sou eu para representar alguém ou alguma coisa? Foi mais para acompanhar o Rodrigo que eu decidi

\footnotetext{
${ }^{5}$ Hospital-dia é uma modalidade de atendimento alternativo à internação psiquiátrica, na qual a pessoa utiliza os serviços da instituição durante o dia, preservando seu direito de cuidado em liberdade.
} 
ir. O horário da oficina, se me lembro bem, era das $16 \mathrm{~h}$ às $19 \mathrm{~h}$ às quartas-feiras, no mesmo dia do ensaio. Teríamos que ir juntos e direto do ensaio para a oficina e mesmo assim chegaríamos um pouco atrasados. A Isabela explicou que faríamos um filme. Um documentário. A única pergunta que eu fiz para ela na ocasião foi se o modelo da câmera interferiria no resultado, na qualidade do filme. Ela disse que sim.

Quando chegou o dia, depois do ensaio, lá estávamos eu e o Rodrigo pegando o metrô para ir até o É de lei, que fica perto da Praça da Sé para participar da oficina. Chegando lá, tocamos o interfone onde estava escrito "É de lei", e dissemos que iríamos para a oficina. Nos deixaram entrar. São alguns andares: escadas e muitas salas. A oficina estava acontecendo em uma sala ampla com janelas e todos, umas 20 pessoas, estavam sentados em cadeiras numa grande roda.

O único Coletivo que eu conhecia era o grupo de teatro que eu participava. Lá, havia integrantes de muitos outros: Coral Cidadãos Cantantes, Paulestinos, Ouvidor 63, ODEC, Preguiça. Percebi que algumas pessoas participavam de mais de um Coletivo ao mesmo tempo e já haviam se conhecido anteriormente. Pela primeira vez tive uma noção da área em que eu estava incluído.

Depois das apresentações, começou a aula. O Fábio, um dos oficineiros, nos falou sobre noções de cinema como enquadramento e composição. Falou também sobre edição, luz e captação de áudio. No fundo da sala, havia uma mesa com chá, café e biscoitos que nós mesmos havíamos combinado antes de levar. Tinha uma cozinha anexa usada para preparar o café. Nas janelas, os fumantes se reuniam para pitar seus cigarros e prosear tentando se conhecer.

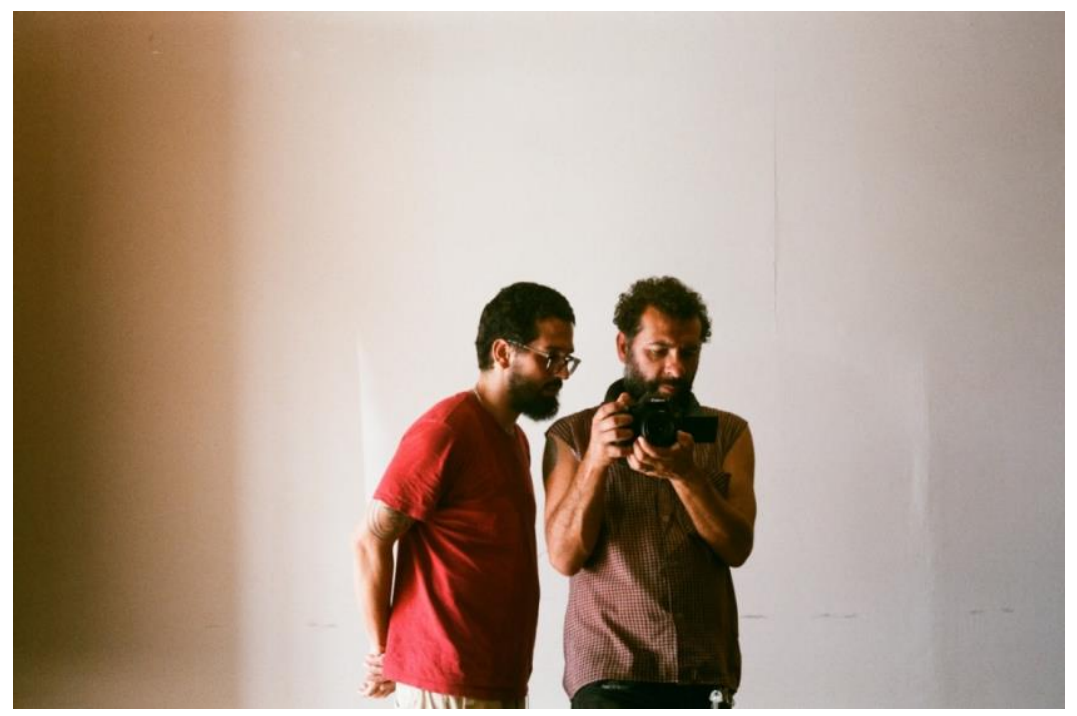

Oficina audiovisual filma Ueinzz. Foto: Yasmin Lopes 
Conheci o Vitão Júnior (também conhecido por Preto Joia depois das oficinas), o Chico, a Ju, o Dani... E logo fizemos algumas experimentações cinematográficas. A ideia era que o pessoal do Coral falasse um pouco sobre o grupo. O Chico, o Vitão Júnior e a Vivi sentaram em três cadeiras uma ao lado da outra que depois de muita discussão resolvemos posicionar em frente à porta. O Dani encarnou o diretor. O Maicon, o câmera. Demorou um pouco até entrarmos num acordo. Mas funcionou. No final, depois de tantas idas e vindas da produção não aguentei e acabei perguntando: Mas Chico, agora explica pra gente por que você fez a cena sem sapatos? Era o fim do primeiro dia. Aos poucos todos foram deixando a sala e foram se dirigindo ao metrô.

A Yasmin estava escrevendo durante toda a oficina as memórias do encontro em um grande papel kraft no chão da sala e lembro de ter me aproximado em certo momento para ver o que ela estava escrevendo e notei a palavra: "Jairo". Meu nome é Jayme, a propósito. Preferi não comentar e ser fiel à memória dela.

Nos outros dias, lembro de termos gravado muitas entrevistas em várias salas diferentes do prédio, sempre na janela. O Fábio armava o tripé, arrumava a câmera e a gente só tinha que apertar o REC. Tinha o áudio também. O Fábio nos ensinou a fazer uma claquete com as mãos para ficar mais fácil de editar depois. Normalmente, alguém ficava com a câmera, outro com o áudio, e um terceiro fazia a claquete. Fora os que estavam assistindo. Gritávamos:

\section{Câmera foi! \\ Áudio foi!}

E alguém batia a claquete na frente do rosto do entrevistado.

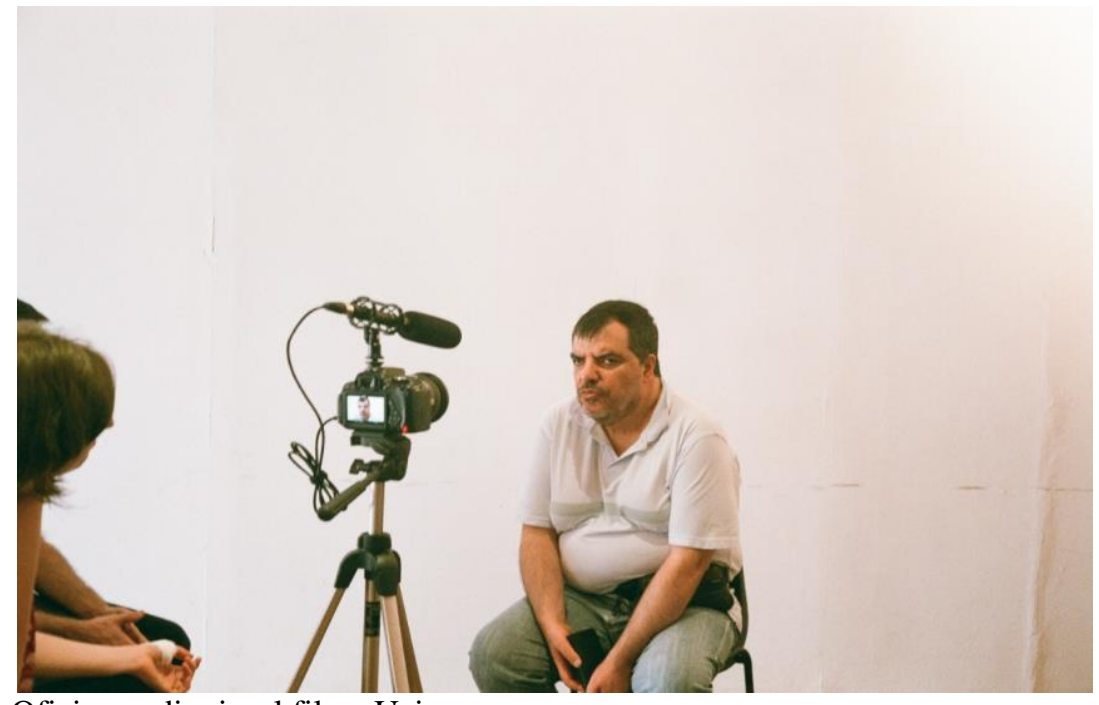

Oficina audiovisual filma Ueinzz.

Foto: Yasmin Lopes 
Nos organizamos em equipes de quatro a cinco pessoas a partir do interesse de cada um em filmar determinado Coletivo. Dessa forma, as equipes eram heterogêneas. Cada uma filmou dois Coletivos em horários fora dos encontros semanais combinados. Toda essa forma de trabalho demandou uma produção intensa, realizada pelos próprios participantes com apoio da equipe técnica. Elegemos, entre os participantes da oficina, um anfitrião de cada Coletivo responsável por fazer a ponte entre as propostas da oficina e os demais participantes do Coletivo, que se envolveram na pesquisa somente nos momentos de filmagem e de exibição do material.

Colocamos numa lousa os nomes de cada Coletivo para nos dividirmos em grupos e cada um escolher quais queriam visitar para filmar. Eu escolhi a ODEC e o Coral Cidadãos Cantantes, ambos com sede na Galeria Olido. Acho que porque me identifiquei mais com os integrantes dos dois. Mas acabei acompanhando e mesmo filmando a Companhia Teatral Ueinzz, da qual participo também. Inclusive, me convidaram para acompanhar as filmagens do Ponto Benedito, outro Coletivo participante da oficina.

Nessa articulação, foi possível observar como as diferentes dinâmicas de cada iniciativa atua nas formas de agenciamento entre as pessoas. O Coral, por exemplo, tem uma pessoa que exerce a função de coordenação, então o nosso contato foi muito mais direto e, além disso, os próprios participantes da oficina organizaram previamente com o grupo a nossa chegada para a filmagem, elencaram possíveis entrevistados e nos introduziram aos outros.

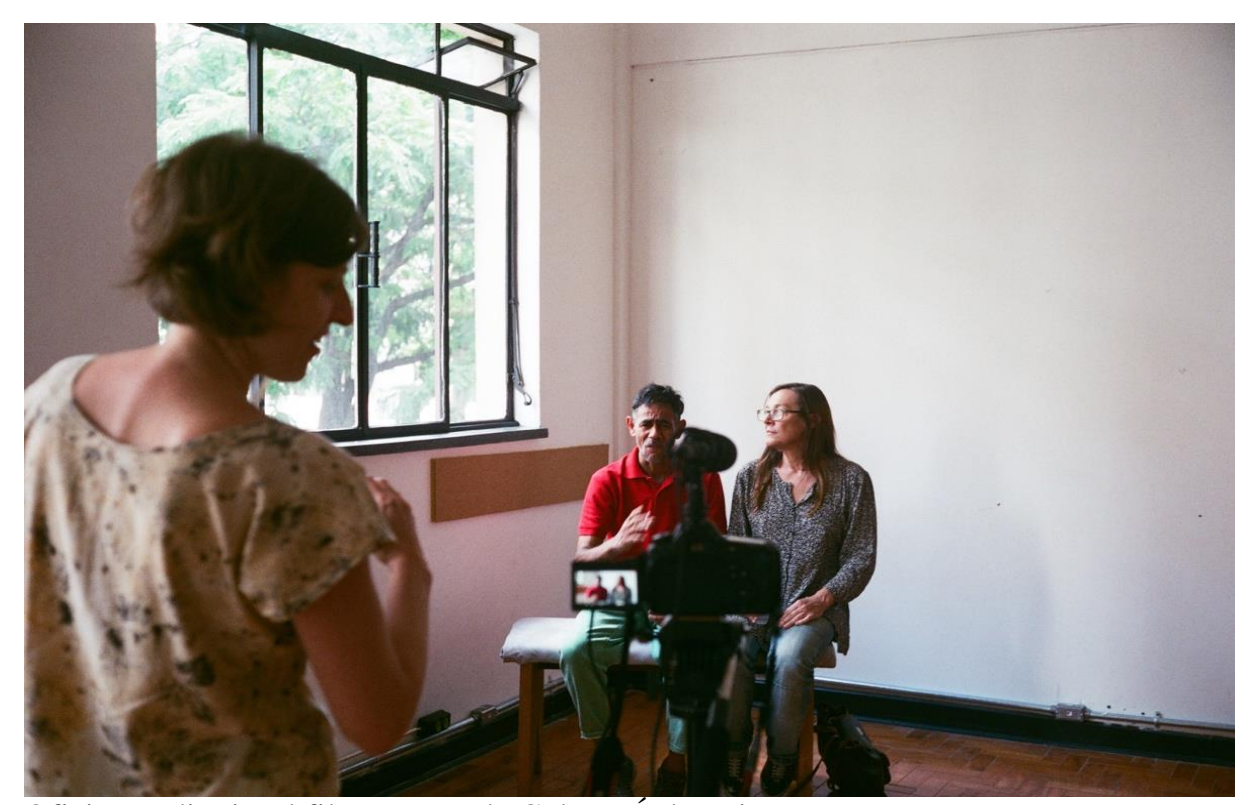

Oficina audiovisual filma Ponto de Cultura É de Lei.

Foto: Yasmin Lopes

A Cia. Teatral Ueinzz já opera em outra dinâmica. Existe uma equipe de coordenação que funciona de forma mais difusa, de modo que havia diferentes interferências entre o meu contato 
com uma das pessoas dessa equipe e a forma como o anfitrião do grupo, que a propósito era o Jayme, exercitou diálogos com o próprio Coletivo. Quando fomos filmar, sentimos dúvida se havia consentimento por parte deles sobre a filmagem. Alguns dos atores não sabiam do que se tratava, outros estavam bastante receptivos.

No dia de filmagem da Ueinzz, a Yasmin e a Isabela quiseram filmar o trajeto até o B_arco, casa do grupo. Lembro da Yasmin me filmando no metrô e eu dando de guia turístico da cidade. Quando chegamos, havia uma profusão de câmeras, tripés e pessoas novas junto com os atores do grupo, filmando tudo. O Ueinzz é um grupo reservado. Estávamos, na época, nos preparando para uma apresentação. E apesar de todas as entrevistas, tudo o que filmamos no dia, não obtivemos permissão para filmar o ensaio. Pensei depois que, se eu tivesse proposto deixar uma câmera num tripé fixa sem ninguém operando, talvez conseguíssemos filmar. Para não dizer que não conseguimos nada da ação, eu filmei uma cena com meu celular. Com ele deitado, que é como o Fábio nos ensinou para a imagem ficar no formato para cinema. Em pé é Instagram. Mesmo assim, fizemos muitas entrevistas. Dentro e fora do teatro.

Foi uma filmagem errante. Sentia receio de invadir, sem saber como e para quem solicitar a autorização e a melhor forma de filmar. Mesmo com certo incômodo, a filmagem foi rica, nada convencional. As perguntas elaboradas nas entrevistas foram inventivas e diferentes do que havíamos planejado, mas trouxeram uma dimensão poética e diálogos inusitados.

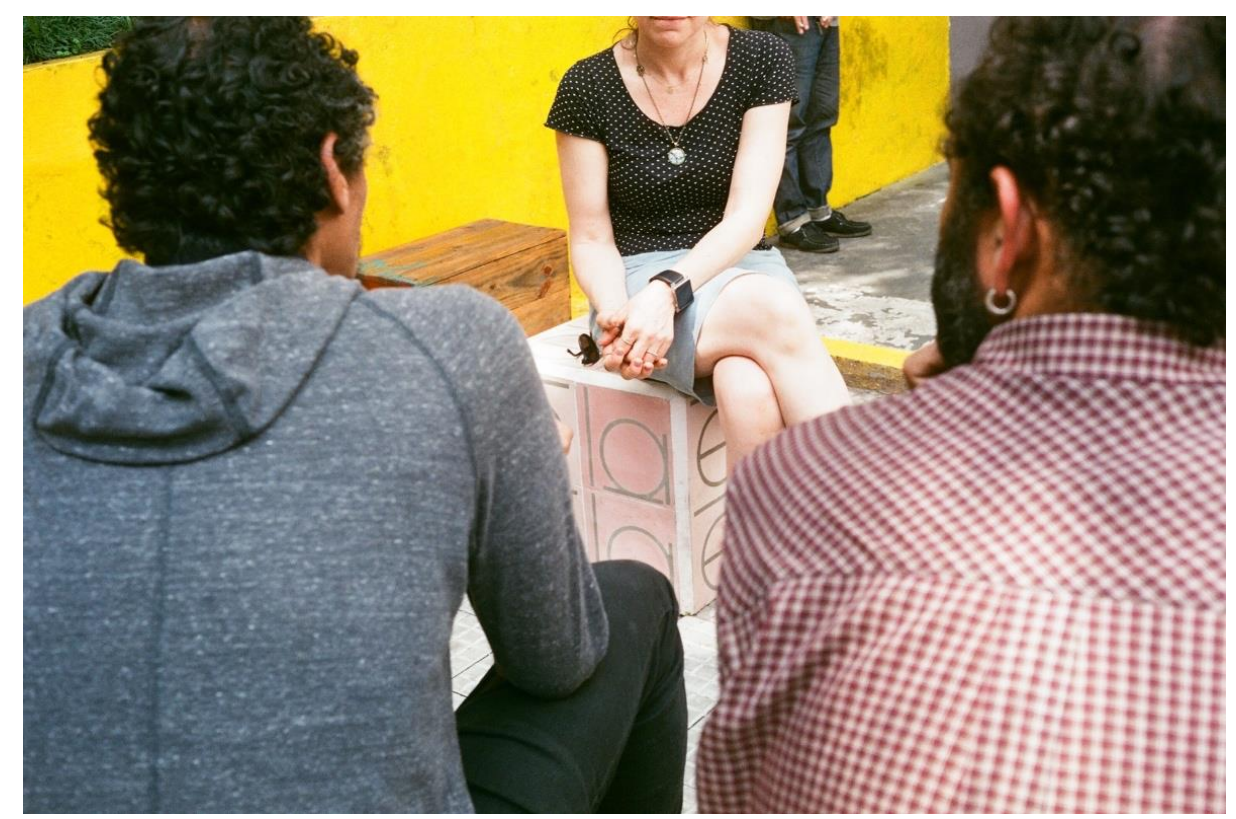

Oficina audiovisual filma Ueinzz.

Foto: Yasmin Lopes

No dia da ODEC, chegamos bem cedo na galeria. Queríamos filmar as pessoas chegando para gravar a rotina do grupo. Lembro do Vitão pegando a chave na secretaria e do Luis 
carregando a caixa de som. Tudo acompanhado por nossas câmeras. Esqueci de citar um oficineiro, o Artur. Ele não estava tão presente, mas dirigiu muitas cenas durante o curso. Nesse dia, ele foi o primeiro a chegar. Filmava o movimento da rua e captou tudo desde o início. Tenho a impressão que ele se revezava com o Fábio.

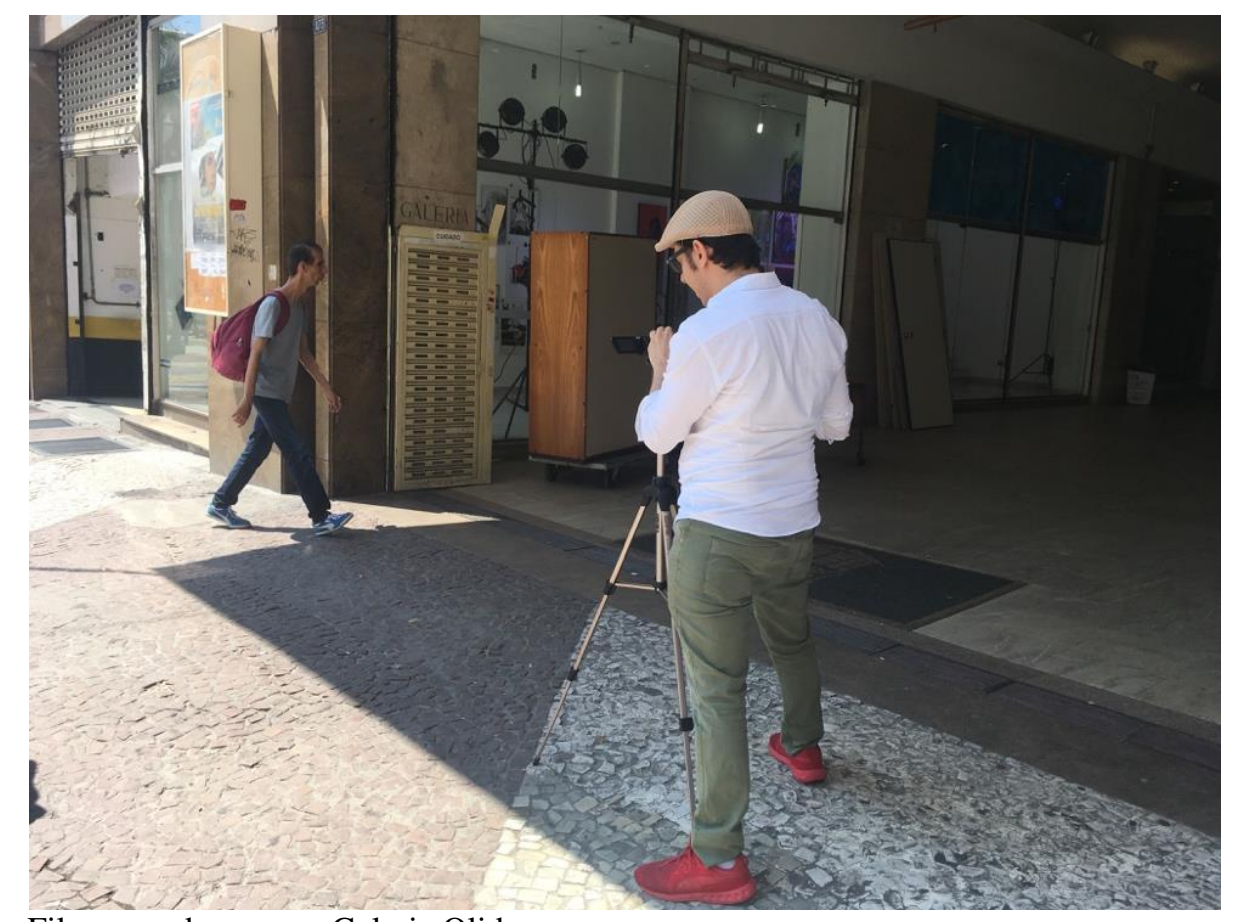

Filmagem de cena na Galeria Olido.

Foto: Isabela Valent

Filmamos todos dançando, inclusive na apresentação de final de ano, em que a Isabela subiu no palco com uma câmera e entrou na dança com a gente. Fizemos vários takes de tudo e entrevistas em vários locais espalhados pela galeria. Lembro do Fábio ter me dado uma câmera para fazer o making off durante uma das entrevistas. Filmei os oficineiros dirigindo, filmando, cuidando do áudio e o pessoal da oficina entrevistando os coordenadores do grupo. Nesse dia, depois da apresentação, fomos juntos para uma celebração na Casa NIS (Núcleo de Investigação do Ser), que é uma casa coletiva que se desdobrou da ODEC. Termino por esquecer a câmera na casa. Quando volto para buscar um tempo depois, eu a recebo com imagens do cotidiano deles realizada pelos frequentadores de forma espontânea.

Esse foi um dos Coletivos onde pudemos estabelecer muitos momentos de exibição das imagens para o grupo. Foi possível perceber que a forma de gestão coletiva operada pela ODEC permite um contato vivo e potente com quem se aproxima, gerando autonomia nos contatos estabelecidos. As propostas que fazíamos não só eram recebidas e respondidas, mas eram cocriadas junto com eles. O anfitrião da ODEC na oficina tecia constantemente pontes, de forma 
que a comunicação e a confiança se deram de forma fluida. A metodologia de produção, criação e manejo de relações que está sendo criada por eles cria condições de participações plurais e libera o agir de todos.

No dia do Coral, que também fica na Galeria Olido, o Artur e a Isabela dirigiram algumas entrevistas no teatro da galeria com os responsáveis pelo grupo e pela galeria. As imagens ficaram lindas. Além do ensaio com todos cantando, também gravamos alguns integrantes cantando separadamente. Naquele dia, um dos coralistas entrevistou a coordenadora do Coral Cênico e formulou perguntas sobre o funcionamento do próprio grupo, sobre as quais, ele depois me contou, nunca havia antes pensado, mas que o preocupavam e interessavam.

Me lembro com alegria e cansaço dessa fase da oficina. Era fim de ano e trabalhamos intensamente. Organizar aquela produção não era fácil. Fiquei muito impressionada com a generosidade dos participantes. Um ajudava o outro a participar. Um dia, saindo de uma entrevista, estava almoçando com Chico, um dos cantores do Coral, e ele estava muito mobilizado por questionamentos sobre como o próprio Coletivo do qual ele fazia parte funcionava, pois estava observando o funcionamento dos outros. Se questionava sobre as formas de gestão coletiva do projeto, elaborava perguntas sobre as formas de financiamento, a relação política de ocupação dos espaços públicos pelos Coletivos, e sonhava possibilidades de outros engajamentos, compreendendo o complexo cenário em que estávamos imersos. As perguntas que eu me fazia no início da pesquisa, agora eram compartilhadas. Estávamos ali, juntos, descobrindo possíveis desdobramentos para estas questões. A pesquisa estava viva e presente para todos nós. Em um dos encontros da oficina, após a realização de algumas das filmagens, os participantes realizaram um debate acerca das diferentes formas de organização e gestão dos grupos. As diferentes experiências foram partilhadas, reconhecemos diferenças e proximidades. As estratégias de uns inspirando os outros. Uns passaram a frequentar os Coletivos dos quais os outros participavam. Relações vinculares se instauraram e se intensificaram. Parcerias se estabeleceram. Críticas e soluções foram compartilhadas. O reconhecimento das habilidades e criações de cada pessoa ou grupo foi reconhecida. 


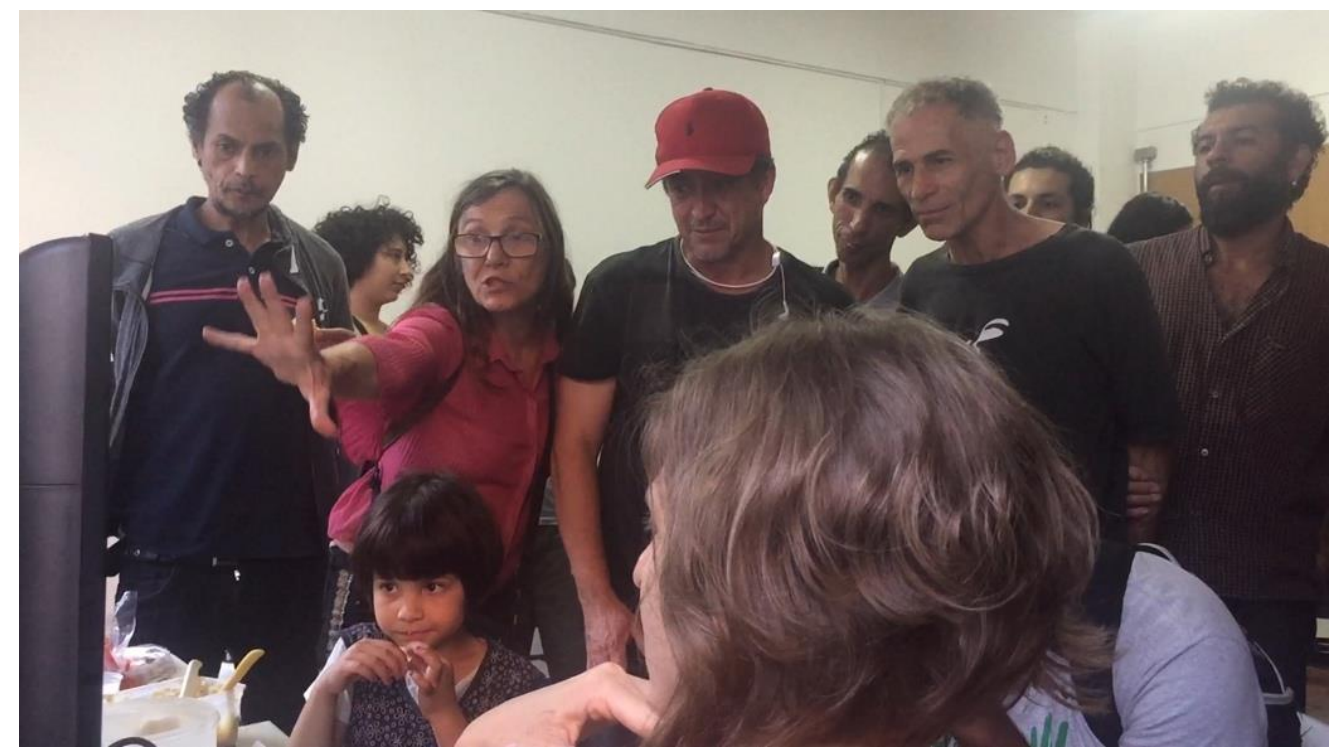

Frame do filme Incomuns em cena da oficina audiovisual em andamento Foto: Isabela Valent

Isabela estava presencialmente em todas as filmagens, bem como durante todos os dias da oficina. Mas chegou um momento em que a coisa esquentou. Passadas as entrevistas e as visitas aos Coletivos, mudamos para uma sala um pouco menor e com menos janelas. Um dos participantes da oficina começou a não se sentir muito bem. Ele surtou, na verdade. Lembro que estávamos na sala menor quando ele ficou em pé e começou a levantar a voz. Um outro participante o enfrentou e a situação começou a ficar tensa. Imagino que todos os integrantes da oficina, incluindo os oficineiros, estão habituados com esse tipo de situação. Muito porque os Coletivos são formados por pessoas em situação limite, seja por vulnerabilidade social causada pela falta de moradia, adicção a substâncias ilícitas, saúde mental, entre outras. A Isabela se colocou entre os dois e conseguiu acalmar os ânimos com apoio de todo o grupo. Mas, infelizmente, o garoto do Ouvidor não voltou mais a frequentar a oficina. Nem ele, nem uma garota também do mesmo coletivo. Houve baixas. Um outro rapaz de um Coletivo chamado Paulestinos, que atua na região denominada Cracolândia em São Paulo, se comprometeu a fazer a ponte entre a oficina e o grupo e parecia empolgado, mas depois sumiu. O Paulestinos e a Ouvidor 63 acabaram ficando fora do documentário

A oficina durou ao todo uns dois meses, eu acho. Alguns dos filmes de cada coletivo, editados pela Isabela, Fábio e Yasmin, foram exibidos para os grupos durante os dias e horários de encontro nos próprios locais onde eles se reúnem. Para mim, o encerramento foi em um evento que não necessariamente estava ligado à oficina, mas marcou em minha memória o final do processo. A oficina, como já disse, aconteceu do meio para o final do ano, e calhou do seu término ficar próximo da festa de final de ano do É de lei. 
Todos estavam lá. Dançamos, comemos, bebemos e nos conhecemos ainda mais. Foi uma noite animada com música, amigos e petiscos. A confraternização durou até quase a hora de o metrô fechar. Quando fui embora, lembro que meu único receio era de não ver mais aquelas pessoas reunidas ali para fazer um filme. Mas, por sorte, e corroborando a minha intenção quando tudo começou, os vínculos que fiz com as pessoas e Coletivos que participaram do processo se estendem até hoje, quase dois anos depois da oficina ter acabado, em um processo que só tem crescido e, inclusive, gerado frutos como o caso deste relato.

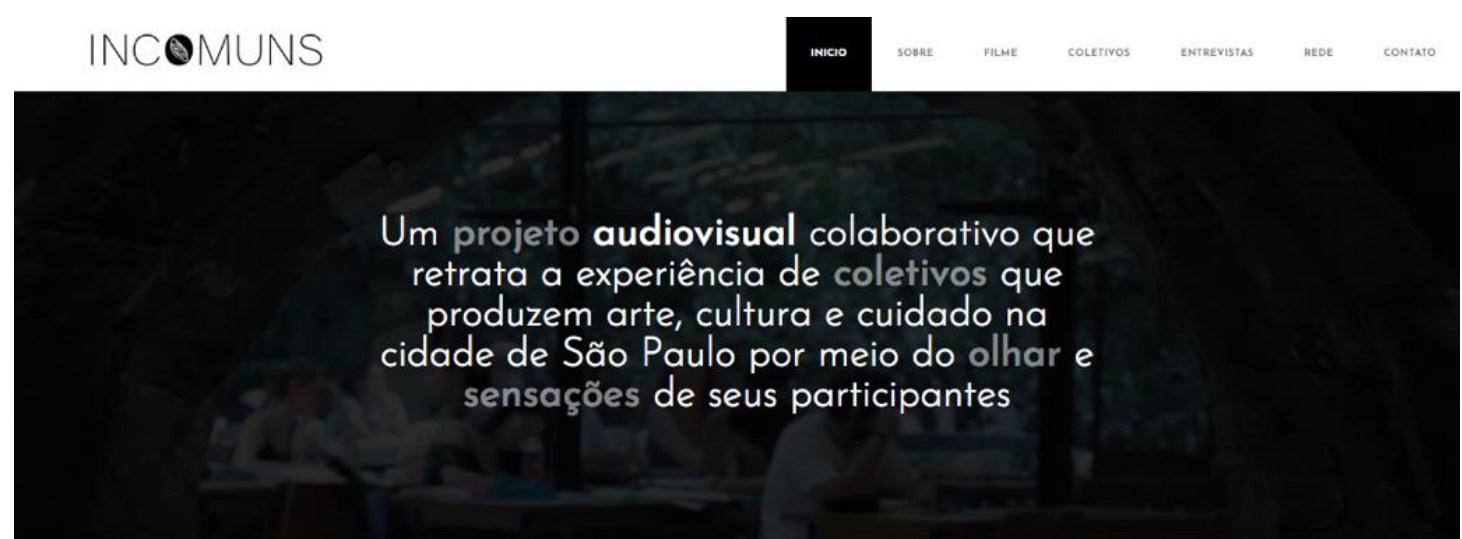

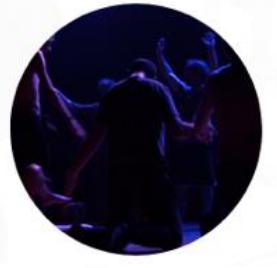

Coletivos incomuns

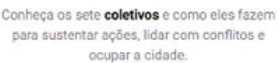

OLHA SO

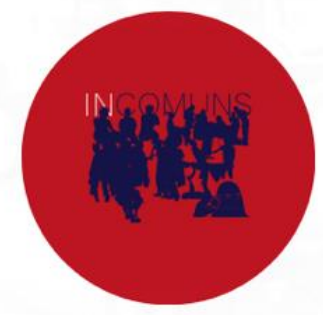

Filme incomuns

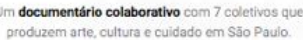

ASSISTA

Captura de tela site Incomuns, com o acervo audiovisual gerado

Para a realização do documentário, fizemos uma parceria com outro editor, o Bruno, que também contribuiu com a elaboração do roteiro. Este olhar mais distanciado, de quem não participou das filmagens, foi crucial para a força da montagem do filme, que chamamos de Incomuns.

Finalmente, chegou o dia da primeira exibição do filme que fizemos. Incomuns foi exibido no cinema da Galeria Olido, casa do Coral Cidadãos Cantantes e da ODEC. Já havíamos assistido, na sede de cada Coletivo, os curtas sobre cada um e tivemos uma boa ideia sobre o resultado do trabalho que havíamos feito. 


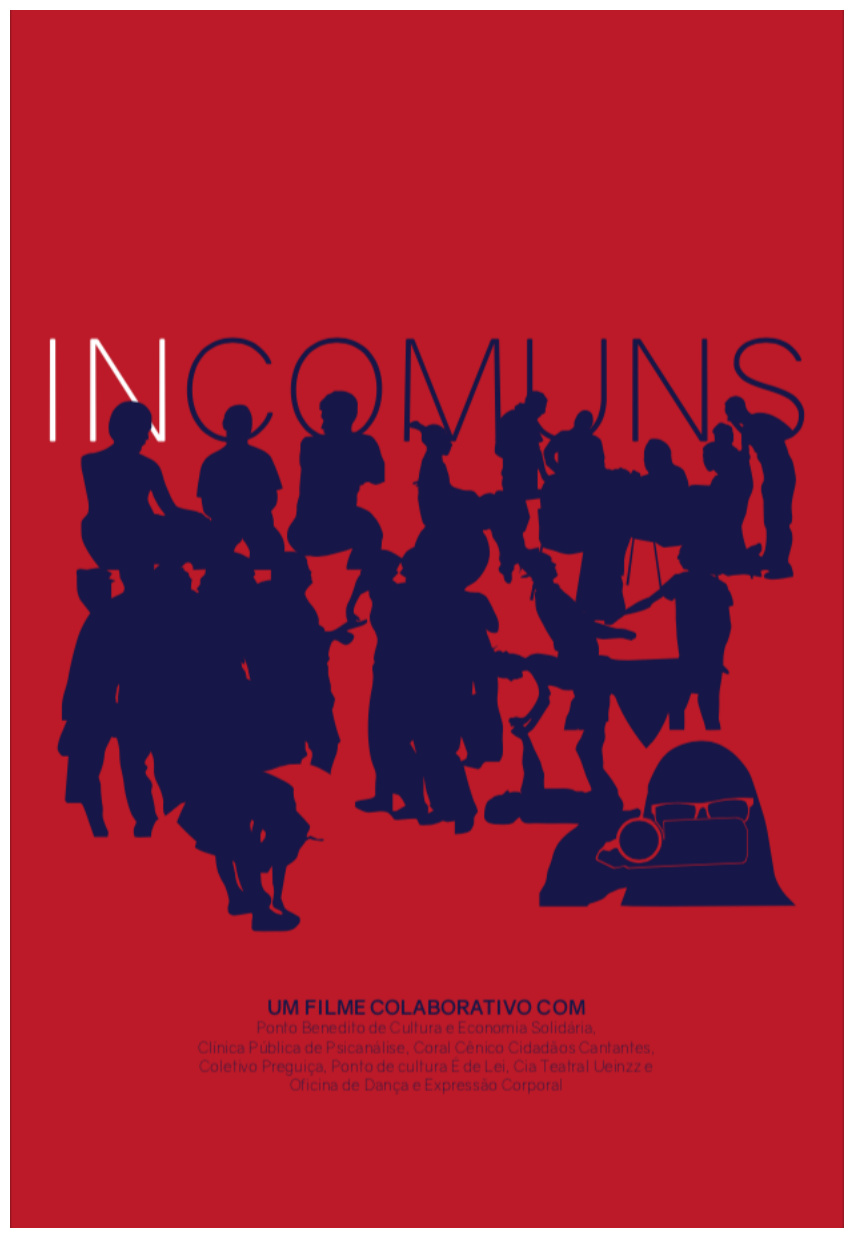

Cartaz do filme Incomuns.

Arte: Maura Grimaldi

Era uma quarta-feira de manhã, dia e horário do ensaio do Coral Cênico Cidadãos Cantantes. Todos os participantes da oficina estavam convidados. Mas, se atentarmos para o fato de que alguns dos participantes não se comunicam por e-mail, telefone, WhatsApp, Facebook, a divulgação para todos fica bem mais trabalhosa. Deve ser feita pessoalmente, nos dias e locais em que os Coletivos se encontram. No dia da exibição, no cinema da Galeria Olido, estavam em maior número os participantes do coral e alguns poucos dispersos de outros Coletivos.

Eu, por ser ator, fui escalado para ler um texto antes da exibição. Tratava-se de um texto que a Isabela havia me enviado contextualizando a exibição do filme e dizendo, entre outras coisas, que o documentário seria exibido também em um festival chamado MEXE, em Portugal, onde ela estava. Os créditos do filme, dizia o texto, também foram pensados para aparecer de uma forma que evidenciasse a natureza colaborativa da produção.

Recados dados, foi exibido, pela primeira vez, o produto de tanto trabalho e objeto da pesquisa de Isabela. Deram o play. Logo de cara, comecei a lembrar de tudo o que passamos juntos. Do trajeto todo percorrido pela gente até ali. Poesia. Dança. Música. Teatro. As pessoas, 
as apresentações, os encontros. Tudo sempre com uma câmera ligada ao fundo, ao lado, perto ou distante, de algum jeito registrando tudo o que aconteceu com a gente nesse período.

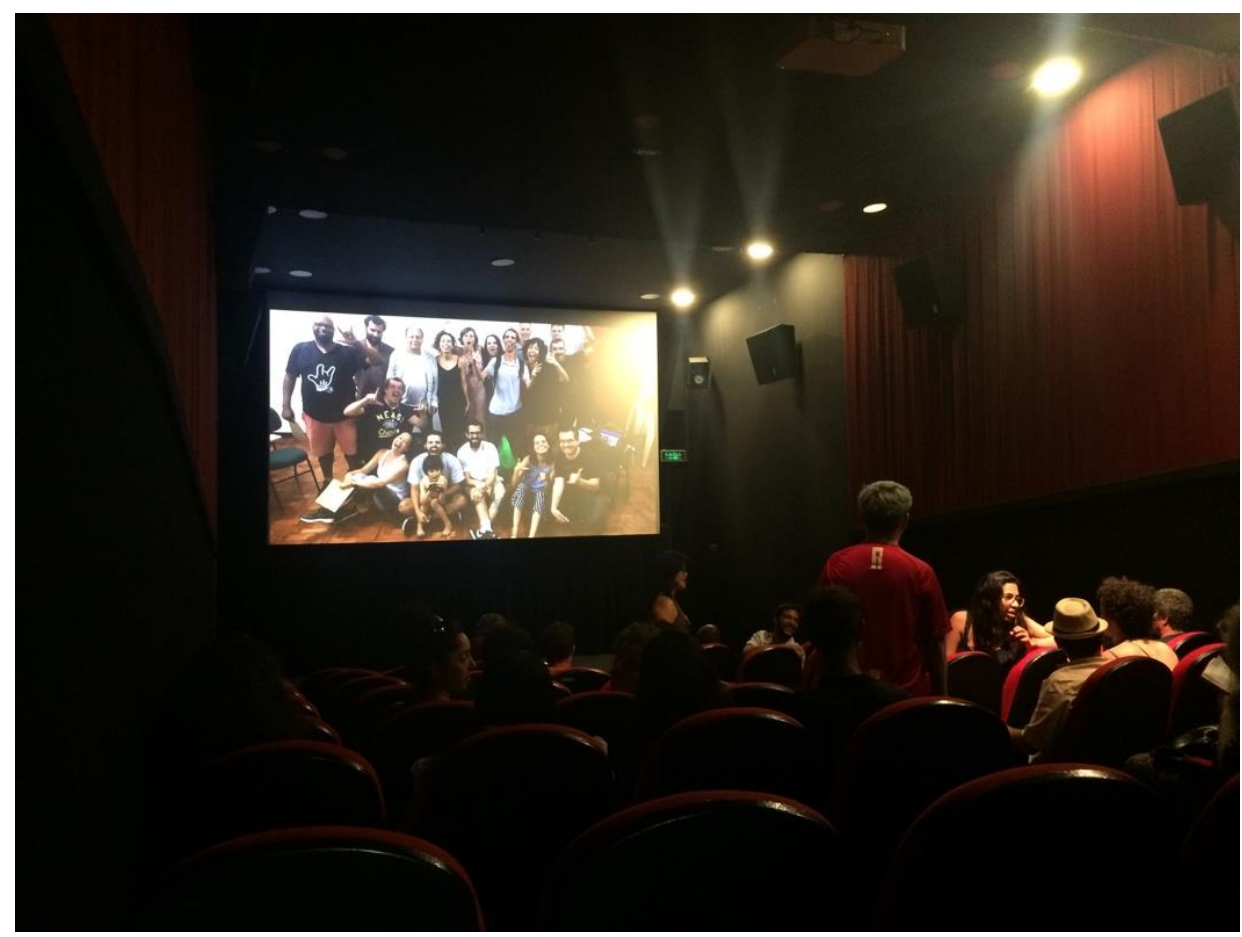

Exibição do filme no cinema da Matilha Cultural. Foto: Isabela Valent

Foi maravilhoso. Mais do que um documentário, da maneira como estamos acostumados a ver - que é mais o caso, aliás, dos vários curtas sobre cada Coletivo que fizemos, Incomuns dança com a gente, tem um clima de suspensão que é próprio da performance, do teatro, da música, de quando estamos em cena. Apesar das críticas feitas depois, de todos os defeitos técnicos que talvez o filme possa ter, ele me envolveu pela sua sensibilidade, pelo olhar poético lançado sobre a própria poesia e me pegou desprevenido ao ver um resultado tão envolvente e emocionante em um processo que ainda continua.

Parece que Incomuns acabou se tornando mais um participante desse múltiplo Coletivo. Aquele cara que chegou agora, corpulento, meio quietão, ainda meio deslocado. Apesar de ele ter chegado faz pouco tempo, sabemos que ele vai voltar a semana que vem. Acho que todos concordam, e não estou falando por mim, que ele pertence ao grupo. Por mais que ele não participe tanto no começo, não faltarão convites para ele interagir, participar, dançar. Do contrário, acredite, a gente já tinha botado ele para correr. E ele pode não querer também. Sem problema. Dormir. Ficar olhando pela janela. Causar confusão. De algum modo ele estar aqui já é o bastante. 


\section{Incomuns entre nós: reflexões sobre a criação coletiva e o conhecimento compartilhado}

O convite aos colaboradores para o desenvolvimento de uma criação buscou evocar manifestações dos participantes como aqueles que criam discursos e imagens, ao invés de reiterar seus lugares como objeto de um discurso, já que o que desejava dar a ver eram os feitos e acontecimentos, evidenciando como se produz e se manifestam essas subjetividades. Esse movimento nos provocava a experimentarmos possibilidades de criação conjunta, compreendendo o dispositivo audiovisual como algo que mobiliza, incita e permite o exercício de um trabalho em composição. Esse jogo instaurou acontecimentos e realizações inusitadas, no qual é necessário reconhecer minha direção, mas também a influência de presenças singulares que culminaram numa invenção coletiva e colaborativa singular. A produção audiovisual, assim, operava como dispositivo de fazer falar, fazer ouvir e fazer ver, criando e desvelando véus que se desdobram daquilo que cada um observa, vive e pronuncia acerca do que produz coletivamente. A estratégia fazer cinema funcionou como um propósito comum que colocou em circulação dinâmicas, apresentando o funcionamento de cada Coletivo e das formas de tessitura desta rede.

Os encontros proporcionados pelas filmagens mostram que esta é uma rede na qual as pessoas já estão em relação umas com as outras. Os Coletivos são iniciativas com membranas porosas, abertas ao fora e ao estranho, que criam uma teia de interações, agenciamentos e acolhimentos na cidade. Essa compreensão orientou a proposta de roteiro do documentário, de modo que o filme apresentasse como os modos de agir coletivos operam neste território. Por isso optei por não identificar no filme o nome e a função de cada entrevistado, compondo áudios da filmagem de um Coletivo com cenas de outros, com o intuito de oferecer ao espectador a sensação dessa teia. Parecia mais importante mostrar as singularidades que essas práticas oferecem para a dimensão da vida em comum do que tentar representar o que seria cada uma delas.

As decisões sobre a construção narrativa do filme ficaram concentradas em mim na etapa de pós-produção, já que não havia mais tempo e condições necessárias para agenciar encontros para uma construção conjunta. Assumi a condução do processo naquele momento, mas a experiência me fez refletir sobre situações frequentes nas iniciativas, nas quais a sustentação das ações dos Coletivos se dá pelo engajamento de algumas pessoas que dedicam parte da vida, inserções institucionais e seus próprios recursos financeiros para sua continuidade. Essa dinâmica, por vezes, parece ser a única saída vista por aquele que têm desejo de construir esses espaços, mas ela também dificulta processos de corresponsabilização, tanto pelos demais 
participantes quanto pelo poder público e a comunidade em geral. Em alguns casos, geram situações de centralização de poder, como no meu caso na finalização do filme.

$\mathrm{Na}$ minha perspectiva, o ato de documentar não mirava a definição de um discurso que nos englobasse a todos, mas a possibilidade de nos comunicarmos e, para tanto, encontrar zonas de ressonância. Dessa maneira, busquei criar situações de encontro e articulação que pudessem amplificar a escuta dessas vozes, por vezes tão dissonantes em relação a um discurso assimilável e encaixável nos formatos institucionais exigidos pelos dispositivos atuais de poder. E também que contemplassem silêncios, ruídos e outras visibilidades, tentando criar saídas para os aspectos colonizadores para os quais a produção acadêmica e a linguagem de projetos insistem em nos arrastar.

A definição da autoria das peças audiovisuais realizadas e do conhecimento produzido pela pesquisa foi outro desafio ético, estético e político no âmbito da produção compartilhada de narrativas. Depois de produzido, a quem pertence o filme? Quem concederá seus direitos de uso? Questões atravessadas pela ideia de propriedade intelectual, que evidencia processos de subjetivação dominantes, na qual um sujeito é convocado a assumir uma autoria, quando no fundo trata-se de uma realização múltipla e coletiva.

Os processos enfrentaram riscos e limites, agiram sobre o que está disposto, embaralharam as linhas dos dispositivos, produzindo incômodos e tensões, assim como a clínica que interfere para poder tratar. É preciso atravessar as turbulências. Os obstáculos para a corresponsabilização coletiva foram muitos. A racionalidade neoliberal, mediante a individualização das questões e das responsabilidades nas diferentes instâncias, constrange as possibilidades de uma ação comum, mas, ainda assim, insisto nesta direção. Por vezes, tensões alcançaram níveis de difícil manejo, e relações institucionais, afetivas ou de parceria foram colocadas em xeque, muitas ficando por um fio. Como sustentar os conflitos e as diferenças sem arrebentar esses fios que nos conectam? A essa pergunta, convido a ouvirmos a voz de Aécio, um dos participantes da oficina e integrante do Ponto Benedito, É de Lei e Cia. Teatral Ueinzz. Em seu depoimento, falando sobre a ação de um dos Coletivo, ele diz:

\footnotetext{
Colhendo o fruto, estamos treinando sempre a repassar isso. Vêm muitas pessoas aqui com necessidade social para colher, para pedir, para pegar, para entregar, para ajudar a levar. Então a gente sente que as pessoas estão livres e aptas para ajudar uma outra. A gente sente que é como começar a puxar correntinha, uma linha. E essa linha, por mais fininha que ela seja, ela não se arrebenta e ela vai se tornando mais forte, mais forte. Cada vez mais forte, à medida que as pessoas vão se dando as mãos. Eu acho que quando a gente começa a se dar a mão, a gente pode circular o mundo, circular o planeta, circular a saúde (....).
}

\footnotetext{
6 Trecho transcrito da entrevista de Aécio Cardoso que pode ser acessada por este link: https://youtu.be/FusyJNW62y4
} 
Assim como a oficina audiovisual, os Coletivos agregam as pessoas com o convite para criar em conjunto, onde cada existência importa. São espaços onde o fazer artístico gera encontros, partilhas e, dessa forma, laços de afeto que geram redes de cuidado e apoio. $\mathrm{O}$ fazer junto, seja uma peça teatral, um espetáculo cênico-musical ou a prática da dança e do movimento propicia uma coletividade que gera pertencimento e acolhimento às singularidades. E esse efeito contribui para o aumento da potência vital de cada um, culminando em espaços para ser e estar em comum e, consequentemente, produzem saúde.

Tal efeito se aproxima da ideia de acolhimento, assim como descreve Monaco (2020) em sua pesquisa com um Coletivo de ativismo bissexual em São Paulo. Para a autora, "a noção de acolhimento diz respeito a iniciativas que, mais do que reivindicar direitos ou políticas públicas, se concentram primordialmente em criar espaços seguros de convivência" (Monaco, 2020:229). A autora desenvolve a noção de monodissidência, no qual os ativistas do coletivo se identificam por uma sexualidade ou afetividade dissidente da "monossexualidade". Porém, os Coletivos “incomuns", acompanhados pela nossa pesquisa, são compostos por comunidades heterogêneas ${ }^{7}$, e esse efeito de acolhimento não provém de um sentimento de identificação a partir da oposição a uma categoria. O que agrega quem participa não é uma categoria identitária, mas sim a abertura ao agir em comum e o convite a estar junto por meio do fazer artístico, cultural ou de cuidado.

Da mesma forma como as criações realizadas pelos Coletivos cunham um "nós" que não é pautado por uma representatividade homogênea, a oficina audiovisual criou esse sentido comum, fazendo-nos acessar a noção de comunidade proposta por Nancy (apud Rena, 2015:223) que afirma que "longe de se reduzir à partilha da identidade, da unidade, etc., a comunidade é o que acontece na co-exposição dos seres uns aos outros, no ser-em-comum sem as pesadas mediações de instituições ou modelos que dirigem as condições das relações.” Agora temos este (In)comum(s) entre nós. Nancy (2008) afirma que a comunidade já está dada a nós, ela não precisa ser produzida, mas, ao mesmo tempo, é uma tarefa infinita renovar esse aspecto comum, que demanda ser reinventado ou reivindicado a todo momento. Assim, minha tarefa com essa pesquisa tem sido de assumir a implicação de ter estes incomuns entre nós e criar estratégias para retornar essa produção aos colaboradores, em comunidade, insistindo em sua dimensão pública.

Para restituir algo à esfera pública "é preciso instituir os restos: tomar nas instituições o que elas não querem mostrar - o rebotalho, o refugo, as imagens esquecidas ou censuradas para retorná-las a quem de direito, quer dizer, ao "público", à comunidade, aos cidadãos" (Didi-

\footnotetext{
${ }^{7}$ A noção de comunidade heterogênea é um "tipo de agenciamento de grupos e coletivos que se constituem a partir das diferenças e singularidades, integrando pessoas, que em muitas ocasiões, encontram-se segregadas" (Valent; Castro, 2017).
} 
Huberman, 2015:206). O autor resgata o sentido do verbo restituir, que indica simultaneamente a transformação de um objeto e sua substituição por outro, para ele "restituir não é atribuir alguma coisa a alguém para que ele anexe e se privilegie [e sobre ele prevaleça] um direito privado. A restituição não implica nem anexação nem a aquisição de propriedade" (ibidem:210). Por essa perspectiva, a ideia de devolutiva do material e a autorização para sua circulação não pode ser traçada por uma linha direta entre aquele que concedeu a entrevista ou o Coletivo que seria seu proprietário legítimo. É evidente que a eles essas imagens dizem respeito, e é importante oferecê-las aos seus olhares, abrindo possibilidades de contemplação coletiva e diálogos sobre suas circulações.

Uma forma de fazer operar essa restituição, sem nos pautarmos pela relação de posse foi a de criar oportunidades de interlocução a partir das criações audiovisuais produzidas coletivamente, gerando espaços para reinventar esse comum entre nós. Nesse sentido, após a finalização da pesquisa, continuo a sustentar gestos de visualização conjunta do acervo audiovisual entre os participantes dos Coletivos e sua divulgação ao público em geral. Mais importante do que representar e legitimar essas práticas pelo conhecimento acadêmico, o foco tem sido que a memória documentada aqueça a articulação crítica entre aqueles que partilham as questões trabalhadas na pesquisa.

O próprio fazer colaborativo da pesquisa nos remete a minha indagação inicial, que era descobrir quais são as forças e condições que mantém esses Coletivos vivos há tantos anos. São espaços onde todos cabem e por isso talvez eles não caibam em nenhum lugar instituído. Descobri que é justamente a não obrigatoriedade de existir que mantém essa força viva, que permite a criação e a coexistência de todos em suas singularidades. É preciso suportar habitar uma teia suficientemente firme e, ao mesmo tempo, aberta para que as diferenças possam existir e o vivo possa ter espaço para brotar. Podemos aproximar esses arranjos coletivos da noção de tentativas, termo elaborado por Deligny (2015) para designar práticas de cuidado que não se baseiam na expectativa de adequação. Para o autor, são estratégias para escapar aos modelos, instituições e lugares identitários, questionando sobre formas de existência fora dos aparelhos de captura e institucionalização. Ele compara a tentativa a uma jangada, uma construção precária cujas tábuas estão suficientemente ligadas para que não se soltem, mas não demasiadamente atracadas para que ela possa navegar (Deligny, 2015).

Os depoimentos gerados pelo processo audiovisual não advogam e não fazem de suas tentativas coletivas um projeto, uma obra ou um plano. E parece ser essa própria posição que libera o curso do agir. Deligny também distingue o fazer do agir, o qual se relaciona com um movimento mais inato do que aquele que se origina de um querer fazer e que opera segundo um 
projeto pensado. Os aparatos de controle, por meio do imperativo da instrução que institui o obrigatório restringem as possibilidades de ação. Assim, é essa possibilidade de ação, livre do "ter que fazer" que parece ser crucial para a qualidade acolhedora desses movimentos coletivos. O que eles permitem acolher é justamente aquilo que ainda não brotou, mas já pulsa e que, se reprimido, pode acabar adoecido e sufocado. Dessa maneira, funcionam como viveiros do comum.

No processo audiovisual relatado habitamos juntos esse emaranhado de questões que perpassam a dimensão da vida em sua perspectiva coletiva e comum. $\mathrm{O}$ dispositivo fazer cinema propiciou a produção compartilhada de conhecimento entre aqueles que vivem problemáticas correlatas, propiciando a criação e o fortalecimento de vínculos e de redes de apoio; o reconhecimento mútuo de universos singulares, mas ressonantes e; o intercâmbio de reflexões e experiências. No âmbito do processo de pesquisa, a prática audiovisual colaborativa permitiu a emergência de analisadores compartilhados e a interlocução criativa entre quem pesquisa e quem colabora, gerando cocriação de processos de análise e apresentação da memória documentada. A produção audiovisual também trouxe a potência de ampliar o alcance dos resultados de uma pesquisa acadêmica, criando oportunidades de apresentação acessível a diferentes públicos e; de fortalecer do protagonismo dos participantes e correalizadores, amplificando a escuta de suas próprias vozes. Mesmo depois de seu encerramento, as peças audiovisuais produzidas e o acervo e o que se desdobrou segue vivo, aberto à novas conexões.

\section{Referências}

DELIGNY, Fernand (2015), O Aracniano e outros textos. São Paulo, n-1 edições.

DIDI-HUBERMAN, Georges (2015), “Devolver uma imagem”, in: E. Alloa (Ed.), Pensar a imagem. São Paulo, Autêntica.

INCOMUNS - site. In: https://incomuns.art.br. Acesso em 08/01/2021.

LAFUENTE, Antonio; GÓMEZ, David; FREIRE, Juan (2018), "El arte de documentar", in Sierra, F.; Leetoy, S.; Gravante, T. (Eds.). Ciudadania digital y democracia. Salamanca, Comunicación Social.

MARQUES, Marcelo de S.; MARX, Vanessa (2020), "Os coletivos em cena: algumas contribuições para o debate”. Simbiótica. Revista Eletrônica, v. 7, n. 3, pp. 08-32 [Consult 20-05-2021], 2020. Disponível em doi.org/10.47456/simbitica.v7i3.33691

MONACO, Helena M. (2020), "Acolhimento como ativismo: ações de um coletivo bissexual na criação de espaços 'monodissidentes"'. Simbiótica. Revista Eletrônica, v. 7, n. 3, pp. 228-251[Consult 20-052021]. Disponível em doi.org/10.47456/simbitica.v7i3.33701

NANCY, Jean-Luc (2008), The inoperative community. Mineápolis, University of Minnesota Press. 
RENA, Alemar (2015), "O comum, a comunidade e a comunicação: entre Jean-Luc Nancy, Michael Hardt e Antonio Negri”. Revista Lugar Comum, n. 45, pp. 221-231[Consult 10/02/2019]. Disponível em https://uninomade.net/lugarcomum/45/

ROUCH, Jean ([1973] 2011), "A câmera e os homens", in J. M. Costa; L. M. Oliveira, Jean Rouch. Lisboa, Cinemateca Portuguesa.

VALENT, Isabela U.; CASTRO, Eliane D. (2017), "Da diversidade ao comum: práticas artísticas, cidadania e políticas sociais". RELACult - Revista Latino-Americana de Estudos em Cultura e Sociedade, v. 3, n. 3, artigo n. 475 [Consult 17-01-2018]. Disponível em: http://periodicos.claec.org/index.php/relacult/article/view/475/245

VALENT, Isabela U. (2019), Criação à deriva: políticas do cuidado em coletivos incomuns. 197 f. Tese (Doutorado em Artes) - Programa de Pós-graduação Interunidades em Estética e História da Arte, Universidade de São Paulo, São Paulo. 


\section{Dedicatória}

Dedicamos este relato à memória de Vitor Paulino Júnior e de Carlos de Oliveira. Vitor, mais conhecido como Vitão ou Preto Joia, nos deixou em junho de 2020, decorrente da covid19. Era coralista do Coral Cênico Cidadãos Cantantes e um belo entrevistador. Carlos, mais conhecido pelas ruas de sampa como Carlão, foi vítima de um atropelamento em setembro de 2020. Era um militante ferrenho da luta antimanicomial, convivente do É de Lei e trabalhador do Ponto Benedito. Suas presenças em vida contribuíram imensamente para este projeto.

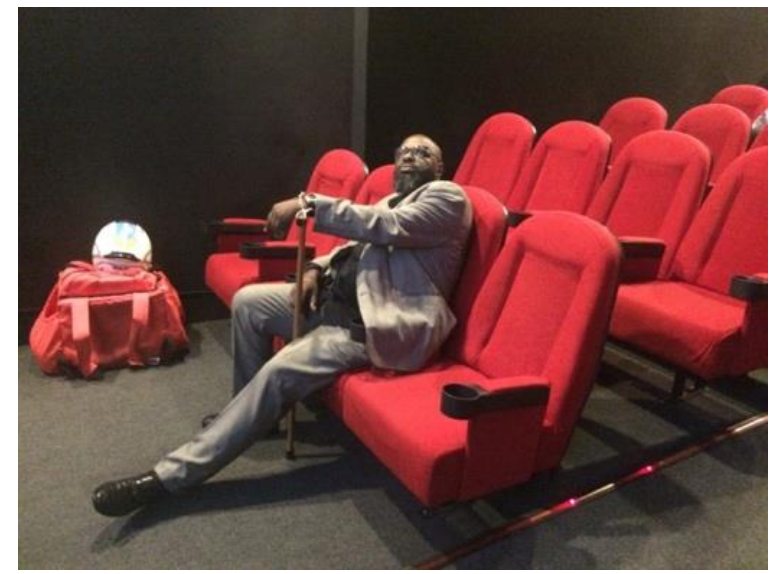

Vitão em uma sessão de exibição do filme Incomuns

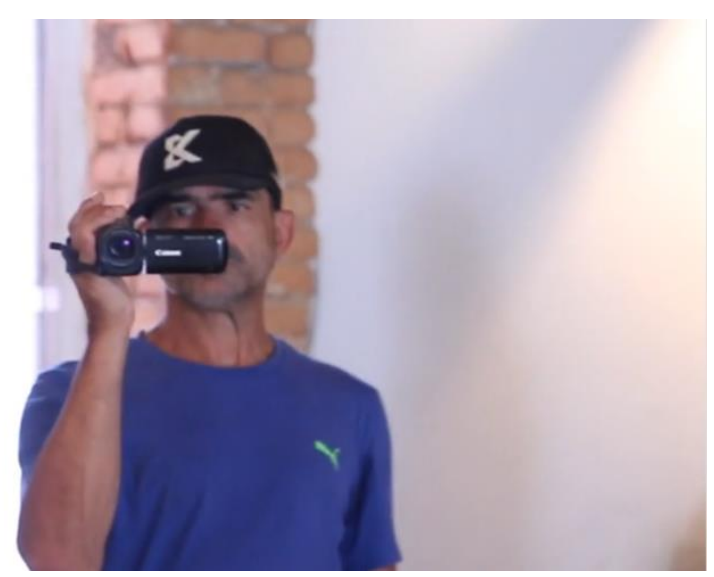

Carlão em cena do filme Incomuns 


\begin{abstract}
From the look and voice of two participants in a collaborative research process, we present the experience of an audiovisual workshop that documented collectives that produce art, culture and care in public spaces in the city of São Paulo, which also welcome people in vulnerable situations. Together, we made the documentary "Uncommons" and a digital collection with audiovisual productions. For dissonant voices to compose the creation process, we practiced experimental forms of work that produced coexistence and circulation in the city. The device established a collective process, articulating networks and exchanges, strengthening the organization of projects and unusual meetings. This report presents how the process was lived from the participants' perspective and reflections on the potentials and challenges of shared production of knowledge and collective creation in everyday actions.
\end{abstract}

Keywords: artistic collectives; audiovisual collaborative processes; shared production of knowledge; mental health.

\title{
Resumen
}

A partir de la mirada y la voz de dos participantes en un proceso de investigación colaborativa, presentamos la experiencia de un taller audiovisual que documentó los colectivos que producen arte, cultura y cuidado en los espacios públicos en la ciudad de São Paulo, que también acogen las personas en situación de vulnerabilidad. Juntos, hicimos el documental "Incomunes" y una colección digital con producciones audiovisuales. Para que las voces disonantes compongan el proceso de creación, practicamos formas experimentales de trabajo que produjeron la coexistencia y la circulación en la ciudad. El dispositivo estableció un proceso colectivo, articulando redes e intercambios, fortaleciendo la organización de proyectos así como reuniones inusuales. En este informe, presentamos como el proceso fue vivenciado por la mirada de los participantes y reflexiones sobre los potenciales y desafíos de la producción compartida de conocimientos y la creación colectiva en acciones comunes.

Palabras clave: colectivos artísticos; procesos colaborativos audiovisuais; producción compartida de conocimientos; salud mental. 